\title{
Multi-Criteria Decision Making Approach Regarding the Choice of University for Postgraduate Studies
}

\author{
Violeta Cvetkoska ${ }^{1} \&$ Dragana Spasevska ${ }^{2}$ \\ ${ }^{1}$ Faculty of Economics-Skopje, Ss. Cyril and Methodius University in Skopje, Skopje, Republic of Macedonia \\ ${ }^{2}$ Skopje, Republic of Macedonia \\ Correspondence: Violeta Cvetkoska, Faculty of Economics-Skopje, Ss. Cyril and Methodius University in Skopje, \\ Blvd. Goce Delchev, 9V, 1000, Skopje, Republic of Macedonia, Tel: 389-2-3286-920. E-mail: \\ vcvetkoska@eccf.ukim.edu.mk
}

Received: October 1, 2015

Accepted: October23, 2015

Online Published: November 25, 2015

doi: 10.5539/ibr.v8n12p116

URL: http://dx.doi.org/10.5539/ibr.v8n12p116

\begin{abstract}
The problem set in this paper regards how to make the choice of University for postgraduate studies. The multi-criteria decision making approach is suggested to be used for solving this problem. The idea is to decompose the problem into the following elements: goal-choice of University for postgraduate studies; criteria that contribute to achieving the goal and that can be of quantitative or qualitative nature; and alternatives-Universities that the choice will be made from. For such problem a hierarchical model can be built, and it can be solved by using the analytic hierarchy process (AHP). The objective of this research, which will be conducted in the form of a questionnaire among the best fourth-year students from Ss. Cyril and Methodius University in Skopje, Faculty of Economics-Skopje, is to determine how many of them will continue their education in postgraduate studies, and where, as well as to identify the criteria that are important in their opinion when choosing a University. Once the participants' answers are received, two groups of criteria that are important regarding the choice of University (in Macedonia and abroad) will be created, and thus two groups of participants will be formed. The choice of criteria will be made according to the arithmetic mean, and if the number is high then factor analysis will be used for their reduction. Afterwards, the participants will be introduced to the AHP method and for combining the individual judgments in group judgment; the geometric mean will be used. The University that is the best choice for each of the participants will come as a result of the ranking of the overall priorities of the alternatives.
\end{abstract}

Keywords: university selection, postgraduate studies, multi-criteria decision making approach, analytic hierarchy process, group decision making

\section{Introduction}

Every student has his/her own currency with which he/she will be "sold" on the labor market after graduating. On the one hand, this currency incorporates the students' knowledge, and on the other hand, the students' personal characteristics. Investing in knowledge increases the net worth of the individual. Hence the motive for writing this paper is to determine how many of the best fourth-year students (with a GPA of over 8.5) from the most prestigious institution of higher education in the field of economy and business in Macedonia, the Faculty of Economics-Skopje within the Ss. Cyril and Methodius University in Skopje, wish to continue their education in postgraduate studies, and where (in Macedonia or abroad). Additionally, through this research the criteria that are important for the participants when choosing a University will be identified. The problem of choosing a University can be decomposed into the following elements: goal, criteria, and alternatives and for the purpose of solving this problem the well-known MCDM (multi-criteria decision making) method-analytic hierarchy process-will be used.

As for the participants who wish to continue their education in postgraduate studies, two groups will be formed. The first group will consist of participants who want to continue their education in Macedonia, and this group will determine the criteria that are significant for the choice of University for postgraduate studies in Macedonia whereas the other group will consist of participants who want to continue their education abroad, and this group will determine the criteria that are important for the choice of University for postgraduate studies abroad. The choice of criteria that will contain one of the levels of the multi-criteria AHP model will be made by assessing 
the arithmetic mean, and if the number of criteria is large then it will be reduced by applying the statistics technique-factor analysis. For each of the alternatives that the participant will make a choice from, the overall priority will be assessed whereas the ranking of these priorities will help in the decision making process for the best University for each student.

This paper is structured in six sections. Along with the introduction, presented in section 1, section 2 covers a review of the existing literature. The research objectives and methodology are explained in section 3 , and the description of the research instrument is explained in section 4 . The analytic hierarchy process is presented in section 5 , and the conclusion is given in section 6 .

\section{Literature Review}

Based on a literature review of Vaidya and Kumar (2006) which contains 150 articles published in international journals in the period from 1983 to 2003 the analytical hierarchy process is applied for solving certain problem in the following areas: personal (26 articles), engineering (26 articles), social (23 articles), manufacturing (18 articles), industry (15 articles), government (13 articles), other (sport, management,...) (12 articles), education (11 articles) and political (6 articles).

Ho (2008) reviews the literature for applications of integrated analytic hierarchy process with another method. 66 articles which are published in international journals are included in this review referring to the period from 1997 to 2006. Based on this review AHP is mainly integrated with mathematical programming (33 articles) followed by Quality Function Deployment (QFD) (16 articles) and meta-heuristics (8 articles), SWOT analysis (5 articles) and Data Envelopment Analysis (DEA) (4 articles).

AHP has various applications in high education. Gibney and Shang (2007) use AHP in the process of selecting a dean. Rouyendegh and Erkan (2012) use fuzzy analytic hierarchy process (FAHP) in selecting the most adequate academic staff. Zhang, Yu, Yang, and Du (2014) proposed AHP model for estimating the faculty number of each school within the university. Besides this, for firms to be able to choose the best university for collaboration Salimi and Rezaei (2015) use fuzzy AHP. Because in the focus of this article is the application of AHP when choosing university for postgraduate studies, what follows is an explanation of the articles with such application in the existing literature.

In order to determine which factors influence international students' choice for postgraduate studies at Universities in Malaysia, Dahari and Abduch (2011) reviewed studies conducted in many countries (Jackson, 1982; Mansky \& Wise, 1983; Paulsen, 1990; Montgomery, 2002; Avery \& Hoxby, 2004; Long, 2004; Chen \&Zimitat, 2006; Drewes \& Michael, 2006; Ivy, 2008; Hsieh, 2010). In their study they decided to use the following 8 factors: price, offered programs, prominence of academic staff, promotion, facilities, environment, convenience, and scholarship. To assess the level of importance of each of the selected factors they used the multi-criteria decision method AHP, and the participants included are 135 international postgraduate first-year students at one of the Universities in Malaysia. The authors classified the analysis of AHP in 6 categories (according to gender: male and female, according to origin: respondents from Southeast Asia (SA), Middle East (ME) and Western countries (WC), and category of all respondents. According to the obtained results (for category of all respondents) it is determined that the most important factor which influences students' choice for postgraduate studies at Universities in Malaysia is programs offered with a priority of 0.245 , and what follows are: price, facilities, prominence, promotion, convenience, scholarship, and environment, with priorities: 0.190 , $0.108,0.100,0.099,0.089,0.087$, and 0.081 , respectively.

The AHP method enables to check whether the judgments of the decision makers are consistent. Therefore, firstly the Consistency Index (CI) is calculated and then it is used for calculating the Consistency Ratio (CR). If the value of the CR is lower than or equal to $0.10(10 \%)$, the inconsistency is considered acceptable, but if the opposite is true, then it is recommended to review and revise the pairwise comparisons. More details on consistency can be found in (Saaty, 2012, pp. 80-84). For all categories of respondents in the study of Dahari and Abduch (2011) the value of the CR does not exceed the limit which means that the identified inconsistency is acceptable.

Tas and Ergin (2012) create an AHP model for the problem of choosing a University in the United States in which Turkish students will enroll for an MBA. Based on the conducted interviews with professors/education counselors, student survey applications, as well as an analysis of previous research, the following twelve criteria are identified: university tuition fees, university location, financial assistance, brand awareness in the home country, the university's brand name, international recognition, national survey ranking, accreditation, home university professors, post-graduation job and career prospects, $\mathrm{PhD}$ program, and education period. The selected criteria are explained in Tas and Ergin (2012, pp. 148-149). To assess the relative importance of the 
criteria a survey was designed and it was conducted on third-year and fourth-year Turkish students studying at private University at the Department of Management. 152 surveys were included in the study, and according to the obtained results it was determined that the most important criterion was post-graduation job and career prospects with a priority 0.213 , followed by: international recognition, accreditation, brand awareness in the home country, national survey ranking, university location, university tuition fees, $\mathrm{PhD}$ program, financial assistance, the university's brand name, education period, and home university professors, with priorities: 0.207 , $0.147,0.085,0.076,0.067,0.045,0.043,0.041,0.035,0.028$, and 0.014 , respectively. The value of the consistency ratio does not exceed the limit $(\mathrm{CR}=0.10)$ which means that the identified inconsistency is acceptable. To evaluate the alternatives, i.e. the 8 universities in the United States (University of Texas, University of Michigan, Carnegie Mellon University, University of North Carolina, University of Minnesota, Indiana University, Emory University, and Washington University) based on the criteria, as respondents were selected professors/education counselors. According to the obtained overall priorities for the alternatives it was determined that the University of Texas is the highest ranked (0.239), followed by the University of Michigan (0.170), and Carnegie Mellon University (0.139) in third place.

Until now the AHP method has not been applied in Macedonia for solving the problem of choosing a University for postgraduate studies. The research that will be conducted will enable the development of an AHP model for the choice of University for postgraduate studies in Macedonia, and an AHP model for the choice of University for postgraduate studies abroad, which will afterwards be solved.

\section{Objectives and Research Methodology}

The objectives of the research are:

- Determining how many of the best fourth-year students (further on participants) from Ss. Cyril and Methodius University in Skopje, Faculty of Economics-Skopje, have clearly defined goals for their future;

- Determining how many of the participants wish to continue their education in postgraduate studies;

- Determining how many of the participants that wish to continue their education in postgraduate studies, will apply right after graduating, and how many participants plan to continue their education in postgraduate studies after gaining work experience;

- Determining the program in which the participants wish to continue their education in postgraduate studies;

- Determining how many of the participants wish to continue their education in postgraduate studies in Macedonia, and how many wish to apply abroad;

- Determining the criteria that are important for the participants in the choice of University for postgraduate studies (separately for Macedonia and for abroad);

- Developing an AHP model for the choice of University for postgraduate studies in Macedonia;

- Developing an AHP model for the choice of University for postgraduate studies abroad;

- Assessing the priorities of the criteria in the AHP model for the choice of University for postgraduate studies in Macedonia;

- Assessing the priorities of the criteria in the AHP model for the choice of University for postgraduate studies abroad.

The research will be conducted through a questionnaire (described in section 4), and the AHP method will be used for the purpose of assessing the priorities of the criteria (described in section 5).

\section{Description of the Research Instrument}

Through the posed questions in the questionnaire, information will be gained about the participants' sex and age, the Department that they study at, their GPA, whether they have clearly defined goals for their future, where they see themselves in five years' time, whether they have their future goals written down, whether after graduating or after gaining initial work experience they wish to apply for postgraduate studies, in which program they would like to continue their education in postgraduate studies, whether they wish to continue their education in postgraduate studies in Macedonia or abroad, and in relation to where they would like to continue their education in postgraduate studies (Macedonia or abroad) to state maximum 9 criteria that they view as important when choosing a University. The questionnaire is given in Appendix.

The participants in this research will be the best fourth-year students (with a GPA of over 8.5) from the Ss. Cyril 
and Methodius University in Skopje, Faculty of Economics-Skopje, and the questionnaire will be given to them in the summer semester of the academic 2015/2016.

The questionnaire will not be anonymous because the whole concept of the research is that after a period of 5 years the same participants will be surveyed once again so as to see whether they have achieved their goals. Aside from this the participants will state criteria that according to them are important when choosing a University for postgraduate studies in Macedonia or abroad, and for that purpose two groups of criteria will be created. The first group will contain all of the stated criteria that are important for the choice of University for postgraduate studies in Macedonia, it will be distributed via email among the participants who wish to continue their education in Macedonia; while the other group will contain all of the stated criteria that are important for the choice of University for postgraduate studies abroad, and it will be distributed via email among the participants who wish to continue their education abroad. The participants will be asked to grade the criteria on a scale of 1 to 5 ( 1 meaning the least important, and 5 meaning the most important), and they can grade different criteria with the same grade. Once the answers from the participants are received, the average score of importance of each criterion will be assessed, and 9 most important criteria from both groups will be chosen. If the number of criteria is high then factor analysis will be used for the reduction of the criteria. The chosen criteria will serve as an input for the multi-criteria AHP model. Subsequently, two AHP models will be constructed, so that one of them will contain criteria for the choice of University for postgraduate studies in Macedonia, while the other will contain criteria for the choice of University for postgraduate studies abroad. Assessment of the criteria priorities and the choice of University are explained in the following section.

\section{The Analytic Hierarchy Process (AHP)}

Thomas L. Saaty developed the Analytic Hierarchy Process in the late 70s of the XX century (Saaty, 1977) for the purpose of solving complex problems which can be decompos into the following elements: goal, criteria, sub-criteria and alternatives. Hunjak and Begicevic (2005, p. 173) point out that in cases in which the decision (the choice of some of the given alternatives and their prioritizing) is based on several criteria/sub-criteria, as one of the most widely exploited methods for decision making is the analytic hierarchy process.

The application of the analytic hierarchy process can be explained through these 4 steps:

1) In regards to the decision problem, a hierarchical model that consists of a goal, criteria, sub-criteria, and alternatives, is developed, so that the goal being at the top is followed by the criteria, sub-criteria, and finally the alternatives. Studies show that people can simultaneously deal with maximum 9 elements (Saaty, 1980, 1990b), which is in fact the maximum number of elements on every level of the hierarchical structure. Figure 1 demonstrates the general AHP model.

Except being used by single decision maker the AHP can be used in group session as well. The participants who wish to continue their education in postgraduate studies in Macedonia or abroad will be introduced to the AHP method (by explaining the methodological and mathematical basics of the method and presenting examples for its application). The hierarchical model that will be developed after the conducted research on the participants will consist of goal-a choice of University for postgraduate studies; criteria that will be chosen according to the average score of importance of each criterion or through factor analysis; and alternatives that will represent the Universities chosen by each participant. The number of criteria that will be chosen for the multi-criteria AHP model for the choice of University for postgraduate studies will not be over 9, and the same goes for the alternatives as well, i.e. the Universities that each participant will take into consideration.

2) In this step it is necessary to compare in pair the elements of each hierarchical level. The decision maker compares in pair two criteria regarding the goal, chooses which one is more important and specifies a judgment of how much more important that criterion is by using the Fundamental Scale for Pairwise Comparisons (Saaty, 2012, p. 73), demonstrated in Table 1. This is done for every pair of criteria. Next, the decision maker compares in pair the alternatives regarding each criterion. For example, when two alternatives are compared regarding the first criterion, it should be chosen the one that is preferred more, and to specify a judgment of how much more preferred that alternative is by using the same scale. As a rule, it is best firstly to compare at one level the strongest and the weakest elements, and the value to be used as a benchmark when doing the upcoming comparisons (Saaty, 2012, p. 268).

The participants who wish to continue their education in postgraduate studies in Macedonia or abroad will have to express judgments for the relative importance of each of the chosen criteria in regards to the set goal.

3) According to the pairwise comparisons, assessment of the weight of the criteria and the priorities of the alternatives is performed, and the overall priority of each alternative is assessed, for more details, see (Saaty, 
1990a). Additionally, the ranking of the overall priorities for the alternatives allows determining which of them represents the best choice. Furthermore, in this step the consistency of judgments is measured by calculating the consistency ratio.

When AHP is used in group session the problem is structured by the group members, they provide judgments and debate about them and make a case for the values of the judgments until a consensus or compromise is reached (Saaty, 2012, p. 263). There are two ways for the numerical values of the judgments of the individuals in group judgment to be combined-one is the consensus vote, and the other is by using a geometric mean (Begicevic, Divjak, \&Hunjak, 2011). For the consensus vote, see (Begicevic et al., 2011, p. 448). In the research that will be conducted among the best fourth-year students from the Ss. Cyril and Methodius University in Skopje, Faculty of Economics-Skopje, a geometric mean will be used to combine their individual judgments. Aczel and Saaty (1983) have proved that in cases when reciprocal judgments are used, the only way to combine the judgments from different individuals is by using a geometric mean.

In this step the priorities of the criteria will be assessed and the participants will have the way of assessing the overall priorities of the alternatives (Universities) explained to them, which will further allow ranking of the alternatives and the best choice.

4) In this step sensitive analysis is performed in order to observe how the change of the inputs (criteria and sub-criteria) influences the final results (priorities of alternatives).

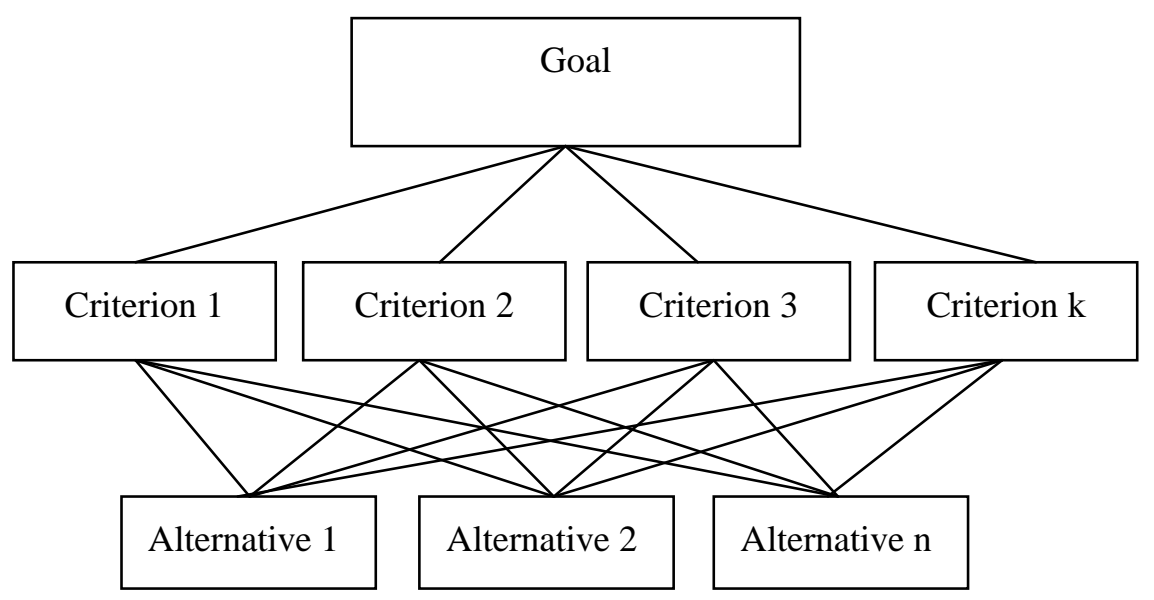

Figure 1. General AHP model

Table 1. The fundamental scale for pairwise comparisons (Saaty, 2012, p. 73)

\begin{tabular}{|c|c|c|}
\hline Intensity of importance & Definition & Explanation \\
\hline 1 & Equal importance & Two activities contribute equally to the objective \\
\hline 3 & Moderate importance & $\begin{array}{l}\text { Experience and judgment slightly favor one activity over } \\
\text { another }\end{array}$ \\
\hline 5 & Strong importance & $\begin{array}{l}\text { Experience and judgment strongly favor one activity over } \\
\text { another }\end{array}$ \\
\hline 7 & $\begin{array}{l}\text { Very strong or demonstrated } \\
\text { importance }\end{array}$ & $\begin{array}{l}\text { An activity is favored very strongly over another; its } \\
\text { dominance demonstrated in practice }\end{array}$ \\
\hline 9 & Extreme importance & $\begin{array}{l}\text { The evidence favoring one activity over another is of the } \\
\text { highest possible order of affirmation }\end{array}$ \\
\hline $2,4,6,8$ & $\begin{array}{l}\text { For compromise between the } \\
\text { above values }\end{array}$ & $\begin{array}{l}\text { Sometimes one needs to interpolate a compromise judgment } \\
\text { numerically because there is no good word to describe it }\end{array}$ \\
\hline Reciprocalsof above & $\begin{array}{l}\text { If activity } i \text { has one of the } \\
\text { above nonzero numbers } \\
\text { assigned to it when compared } \\
\text { with activity } j \text {, then } j \text { has the } \\
\text { reciprocal value when } \\
\text { compared with } i\end{array}$ & $\begin{array}{l}\text { A comparison mandated by choosing the smaller element as } \\
\text { the unit to estimate the larger one as a multiple of that unit }\end{array}$ \\
\hline Rationals & Ratios arising from the scale & $\begin{array}{l}\text { If consistency were to be forced by obtaining } n \text { numerical } \\
\text { values to span the matrix }\end{array}$ \\
\hline $1.1-1.9$ & For tied activities & $\begin{array}{l}\text { When elements are close and nearly indistinguishable; } \\
\text { moderate is } 1.3 \text { and extreme is } 1.9\end{array}$ \\
\hline
\end{tabular}


The advantages of the analytic hierarchy process as a new approach in solving problems and decision making are the following (Saaty, 2012, p. 25): for a wide range of problems that are unstructured it provides a single model, which can be easily understood and which is flexible; in solving problems that are complex it integrates deductive approach and system approach; in the frames of the system it can deal with the interdependence of elements; natural tendency of our mind is to sort the elements of a system at various levels and to group like elements in each level, and the analytical hierarchy process reflects this tendency of the mind; Saaty (2005, p. ix) states that AHP presents a method of relative measurement of intangibles, so that for measuring intangibles it provides a scale of absolute numbers and for establishing priorities it provides a method; one of its basic principles is logical consistency, and it tracks logical consistency of judgments used in determining priorities; it synthesizes results; relative priorities of the factors within the system are taken into consideration and it enables the decision makers to choose the best alternative on the basis of their goals, the analytic hierarchy process does not insist on consensus but on the basis of the various judgments it synthesizes outcome which is representative; and it enables the decision makers to refine the problem definition and to improve their judgment and understanding through repetition.

Besides the advantages, the analytic hierarchy process has its limitations as well and the most frequently mentioned in literature are the following (Begicevic, 2008, p. 115): the fundamental scale for pairwise comparisons is not big enough to compare the hierarchy elements in pairs-connected with some decision problems; numerous pairwise comparisons are necessary for most problems; very often, it is especially difficult to achieve acceptable CR; and alternatives which are not comparable, are not allowed. Begicevic (2008) points out that out of the listed limitations of the AHP method the first and last are mentioned as its biggest limitations, and as for the possibility of expanding the fundamental scale for pairwise comparisons and compare alternatives which at first glance are incomparable, see (Saaty, 2005, pp. 7-8).

\section{Conclusion}

The objective of the research which will be conducted among the best fourth-year students at the Faculty of Economics-Skopje within the Ss. Cyril and Methodius University in Skopje, in the summer semester of the academic year 2015/16 is to determine the number of students who will continue their education at postgraduate studies and the place (whether it will be Macedonia or abroad) and to identify the criteria which they consider important when choosing university.

In order to solve the problem for choosing university for postgraduate studies it is proposed to use multi-criteria method AHP which will firstly be explained at the sample consisted of respondents who want to continue at postgraduate studies. Out of the respondents who want to continue at postgraduate studies in Macedonia we will identify the criteria of importance when choosing university in Macedonia, and analogically out of those who want to continue at postgraduate studies abroad we will identify the criteria of importance when choosing a university abroad. Determining the criteria which serve as input in the multi-criteria AHP model for choosing university for postgraduate studies (in Macedonia or abroad) will be done by calculating the arithmetic mean or by using the statistical technique factor analysis. Assessing the priorities of the criteria will enable to determine which criterion is the most important for the respondents, and which one is the least important. This is especially important for the universities because it provides criteria which are important for the potential students at postgraduate studies and they would be able to act in the direction of their improvement and promotion.

The sample of this study will be comprised of the best fourth-year students at one high education institution in Macedonia and the results will give conclusions which refer only to this sample but in order to make more general conclusions in the next research a wider sample of students can be used who study at the Faculties of Economics in Macedonia, and further on the same can be expanded and include students out of the borders of this country and thus make a comparative analysis. Also, this research can be conducted at the other faculties not only at the faculties of economics.

\section{References}

Aczel, J., \& Saaty, T. L. (1983). Procedures for synthesizing ratio judgment. Journal of Mathematical Psychology, 27, 93-102. http://dx.doi.org/10.1016/0022-2496(83)90028-7

Avery, C., \& Hoxby, C. (2004). Do and should financial aid packages affect students' college choices? In C. Hoxby (Ed.), College choices: The economics of where to go, when to go, and how to pay for it (pp. 239-299). Chicago: University of Chicago Press. http://dx.doi.org/10.7208/chicago/9780226355375.003.0007

Begicevic, N. (2008). Strategic planning of e-learning implementation using multi-criteria decision making models (Unpublished doctoral dissertation)). University of Zagreb, Faculty of Organization and Informatics, 
Varazdin, Croatia (in Croatian).

Begicevic, N., Divjak, B., \& Hunjak, T. (2011). AHP-based Group Decision Making Using Keypads. Int. J. Economics and Business Research, 3(4), 443-458. http://dx.doi.org/10.1504/IJEBR.2011.040953

Chen, C. H., \& Zimitat, C. (2006). Understanding Taiwanese students' decision-making factors regarding Australian international higher education. Int. J. Educ. Manage., 20(2), 91-100. http://dx.doi.org/10.1108/09513540610646082

Dahari, Z., \& Abduh, M. (2011). Factors influencing international students' choice towards universities in Malaysia. African Journal of Business Management,5(26), 10615-10620.

Drewes, T., \& Michael, C. (2006). How do students choose a university? An analysis of applications to universities in Ontario, Canada. Research in Higher Education, 47(7), 781-800. http://dx.doi.org/10.1007/s11162-006-9015-6

Gibney, R., \& Shang, J. (2007). Decision making in academia: A case of the dean selection process. Mathematical and Computer Modelling, 1030-1040. http://dx.doi.org/10.1016/j.mcm.2007.03.024

Ho, W. (2008). Integrated analytic hierarchy process and its applications-A literature review. European Journal of Operational Research,186, 211-228. http://dx.doi.org/10.1016/j.ejor.2007.01.004

Hsieh, Y.J. (2010). The decision-making process of international students in Taiwan: A case study. Paper presented at the Fifth APAIE 2010 Conference, Griffith University, Australia.

Hunjak, T., \& Begicevic, N. (2005). How to choose the most suitable form of implementing e-learning? In B. Aurer, \& M. Baca (Eds.), Proceedings of the $16^{\text {th }}$ International Conference on Information and Intelligent Systems (pp. 169-178). Varazdin: Faculty of Organization and Informatics Varazdin, University of Zagreb.

Ivy, J. (2008). A new higher education marketing mix: The 7Ps for MBA marketing. Int. J. Educ. Manage., 22(4), 288-299. http://dx.doi.org/10.1108/09513540810875635

Jackson, G. A. (1982). Public efficiency and private choice in higher education. Edu. Eval. Pol. Anal., 4(2), 237-247. http://dx.doi.org/10.3102/01623737004002237

Long, B. T. (2004). How Have College Decisions Changed over Time? An Application of the Conditional Logistic Choice Model. J. Econom., 121, 271-296. http://dx.doi.org/10.1016/j.jeconom.2003.10.004

Mansky, C., \& Wise, D. (1983). College choice in America. Cambridge: Harvard University Press. http://dx.doi.org/10.4159/harvard.9780674422285

Montgomery, M. (2002). A nested logit model of the choice of a graduate of a business school. Econ. Educ. Rev., 21(5), 471-480. http://dx.doi.org/10.1016/S0272-7757(01)00032-2

Paulsen, M. B. (1990). College choice: Understanding student enrollment behavior. ASHE-ERIC Higher Education Report No. 6. Washington, DC: The George Washington University, School of Education and Human Development.

Rouyendegh, B. D., \& Erkan, T. T. (2012). Selection of academic staff using the fuzzy analytic hierarchy process (FAHP): A pilot study. TehnickiVjesnik, 19(4), 923-929.

Saaty, T. L. (1977). A Scaling Method for Priorities in Hierarchical Structures. Journal of Mathematical Psychology, 15(3), 234-281. http://dx.doi.org/10.1016/0022-2496(77)90033-5

Saaty, T. L. (1980). The Analytic Hierarchy Process. New York: McGrow Hill Company.

Saaty, T. L. (1990a). How to make a decision: The analytic hierarchy process. European Journal of Operational Research, 48, 9-26. http://dx.doi.org/10.1016/0377-2217(90)90057-I

Saaty, T. L. (1990b). Multicriteria decision making: The analytic hierarchy process. Pittsburgh: RWS Publications.

Saaty, T. L. (2005). Theory and Applications of the Analytic Network Process: Decision Making with Benefits, Opportunities, Costs, and Risks. Pittsburgh: RWS Publications.

Saaty, T. L. (2012). Decision making for leaders: The analytic hierarchy process for decisions in a complex world (3rd ed.). Pittsburgh: RWS Publications.

Salimi, N., \& Rezaei, J. (2015). Multi-criteria university selection: Formulation and implementation using a fuzzy AHP. Journal of Systems Science and Systems Engineering, 24(3), 293-315. http://dx.doi.org/10.1007/s11518-015-5271-3 
Tas, A., \& Ergin, E. A. (2012). Key factors for student recruitment: The issue of university branding. International Business Research, 5(10), 146-153. http://dx.doi.org/10.5539/ibr.v5n10p146

Vaidya, O., \& Kumar, S. (2006). Analytic hierarchy process: An overview of applications. European Journal of Operational Research, 169, 1-29. http://dx.doi.org/10.1016/j.ejor.2004.04.028

Zhang, L., Yu, X., Yang, Z., \& Du, Q. (2014). Human Capital Planning of Faculties in Higher Education Institutions with Analytic Hierarchy Process Model. Journal of Human Resource and Sustainability Studies, 2, 224-229. http://dx.doi.org/10.4236/jhrss.2014.24023

\section{Notes}

Note 1. If the answer to question 10 is affirmative, then do not answer the following questions.

Note 2. If the answer to question 14 is affirmative, then answer question 15, but if it is negative, then skip to question 16.

\section{Appendix}

\section{Questionnaire}

Instructions:

Dear,

The aim of this questionnaire is to gain information as to whether you have clearly defined goals for your future, whether your education will consist only of graduate studies, or if you would like to continue your education in postgraduate studies, where would you like (in Macedonia or abroad), and what criteria are the most important in your opinion regarding the choice of University for postgraduate studies in Macedonia or abroad.

The information gained from your questionnaire will not be used separately, but as part of the whole sample.

Thank you in advance for your time in filling out the questionnaire.

1. Name and surname (insert):

2. E-mail address (insert):

3. Sex (circle your answer):
a) male
b) female

4. Age (insert): years

5. Department (circle your answer)
a) E-business
b) Economics
c) Marketing
d) Management
e) Foreign Trade
f) Accounting and Auditing
g) Financial Management

6. GPA (insert):

7. Do you have clearly defined goals for your future? (circle your answer)
a) yes
b) no

8. Where do you see yourself in 5 years' time:

9. Are your future goals written down? (circle your answer)
a) yes
b) no

10. Will your education consist only of graduate studies? (Note 1) (circle your answer)
a) yes
b) no 
11. Will you apply for postgraduate studies right after graduating? (circle your answer)
a) yes
b) no

12. Are you planning to gain work experience first, and then to continue your education in postgraduate studies? (circle your answer)
a) yes
b) no

13. In what program would you like to continue your education in postgraduate studies?

14. Will you continue your education in postgraduate studies in Macedonia? (Note 2) (circle your answer)
a) yes
b) no

15. What criteria are especially important for you when choosing a University for postgraduate studies in Macedonia? (state 9 criteria at most)

16. What criteria are especially important for you when choosing a University for postgraduate studies abroad? (state 9 criteria at most)

\section{Copyrights}

Copyright for this article is retained by the author(s), with first publication rights granted to the journal.

This is an open-access article distributed under the terms and conditions of the Creative Commons Attribution license (http://creativecommons.org/licenses/by/3.0/). 